Książka Tomasza Dekerta, choć jest opracowaniem stricte naukowym, dzięki kunsztowi autora przydatna jest dla szerokiego grona odbiorców. Z pewnością dużo wnosi w badania nad źródłami teologii chrześcijańskiej i mogą z niej korzystać zarówno ci, którzy tą dziedziną zajmują się na co dzień, jak i ci dla których jest ona nowością. Sądzę, że jest ona atrakcyjna nie tylko dla patrologów czy dogmatyków. Sam pomysł badania źródeł jednej z najciekawszych i ważnych teorii dotyczących zbawienia powinien zachęcić każdego, kto poszukuje głębi wiary chrześcijańskiej. Poznawanie bowiem kontekstów, w jakich rodziły się prawdy wiary, może otworzyć na nie mentalność człowieka współczesnego tak odpornego na dogmaty.

Ks. Szymon Górski - Kielce

\title{
Elżbieta DOŁGANISZEWSKA, Biskup Cyprian z Kartaginy. Świadek wia- ry, Wrocław 2007, Wydawnictwo Wrocławskiej Księgarni Archidiecezjalnej, ss. 104.
}

Postaci wielkich animatorów życia społecznego, politycznego i religijnego zawsze są z chęcią przywoływane i opisywane, a ich życie, działalność i twórczość przypominane są wciąż na nowo. Szczególnie w patrologii, zajmującej się postaciami pisarzy chrześcijańskich pierwszych wieków, znajomość środowiska, życia i dzieł danego pisarza wydaje się nieodzowna. Oprócz standartowych podręczników, które z oczywistych względów przedstawiają tylko najważniejsze informacje biograficzne, ważną rolę odgrywają monografie dotyczące poszczególnych pisarzy, umieszczające ich w konkretnym kontekście oraz prezentujące podstawy ich teologii i swoisty klucz hermeneutyczny do zrozumienia ich twórczości. W ostatnim czasie w Polsce rolę te spełnia częściowo seria Wielcy Ludzie Kościoła, publikowana przez Wydawnictwo WAM. Pojawiają się także inne pozycje poza seriami, które mają za cel przybliżenie tych wybitnych postaci. Jedną z nich jest opublikowana przez Wydawnictwo Wrocławskiej Księgarni Archidiecezjalnej książka Elżbiety Dołganiszewskiej Biskup Cyprian z Kartaginy. Swiadek wiary.

Składająca się z sześciu rozdziałów praca, zgodnie ze słowami autorki, ma „w ogólnych zarysach ukazać sylwetkę - życie i dzieło - tegoż właśnie niezwykłego biskupa, świadka wiary i męczennika z Kartaginy" (s. 8). Autorka z rozmachem zmierza do postawionego sobie celu. W pierwszym rozdziale „Cyprian, biskup Kartaginy" (ss. 9-22) przedstawia życiorys Cypriana w kontekście prześladowanego Kościoła i problemów z upadłymi oraz z kościelną jednością. Drugi rozdział „Dzieła teologiczne biskupa Cypriana” (ss. 23-38) ma za cel ukazanie bogatej spuścizny literackiej biskupa Kartaginy. „Sakrament chrztu zalążkiem jedności Kościoła” to tytuł trzeciego rozdziału (ss. 39-50), 
w którym Autorka zwraca uwagę czytelnika na „Zależność jedności chrztu, Kościoła i Ducha Świętego” (ss. 41-45), na „Rozumienie pojęcia sakramentu” (ss. 45-47) oraz na „Chrzest jako sacramentum” (ss. 47-50). Tematem czwartego rozdziału jest „Autorytet biskupa w Kościele lokalnym (ss. 51-62), który omawiany jest przez Autorkę w czterech wymiarach: „Biskup jako zastępca Chrystusa w Kościele”, „Biskup następca apostołów”, „Sukcesja Piotrowa biskupów” i „Biskup - znak wewnętrznej jedności Kościoła”. „Jedność episkopatu a Kościół powszechny" jest zagadnieniem, którego dotyczy piąty rozdział (ss. 63-72) omawianej książki. W rozdziale tym E. Dołganiszewska analizuje piśmiennictwo Cypriana w aspekcie źródeł jedności biskupów, jedności w wielości oraz Kościoła jako wspólnoty wspólnot. Ostatni rozdział: „Jeden Kościół - Extra Ecclesiam nulla salus” (ss. 73-92) przedstawia jedyność i niepodzielność Kościoła i problem zbawienia w nim oraz ukazuje Kościół jako Matkę. Książka ponadto zaopatrzona jest we wprowadzenie (ss. 5-8), zakończenie (ss. 93-96) oraz bibliografię (ss. 97-102), zawierającą w sumie 72 pozycje.

Z przedstawionego układu treści książki możemy dostrzec, że głównym polem zainteresowań Autorki są zagadnienia eklezjologiczne wchodzące w zakres teologii fundamentalnej. Na tym polu Autorka w doskonały sposób przedstawia nauczanie biskupa Cypriana dotyczące właśnie zagadnień eklezjologicznych, co jest ogromnym plusem omawianej pozycji. To jednak, co jest zaletą tej książki, stało się także jej mankamentem. Autorka, jako doktor teologii fundamentalnej, skupia swoją uwagę niemal wyłącznie na tych zagadnieniach. Wydawałoby się, że zgodnie z przytoczoną już powyżej zapowiedzią, przedstawi sylwetkę tego niezwykłego biskupa. Czyni zadość swoim zapowiedziom, dokonuje tego jednak w bardzo ogólnych zarysach. Przeprowadza analizę postaci biskupa Cypriana z pozycji teologii fundamentalnej, a właściwie jej niektórych aspektów, pomijając całe bogactwo jego myśli teologicznej. Wydaje się, że proste nadanie pracy innego tytułu, czy też doprecyzowanie go, nie wprowadzałoby w błąd czytelników poszukujących syntezy całego życia i nauczania biskupa Cypriana z Kartaginy, która wydaje się bardzo potrzebna na polskim rynku wydawniczym. Prezentowana książka jest cennym przyczynkiem do poznania myśli kartagińskiego biskupa, ale niestety tylko w szczególnym jej wymiarze, jako że do całościowego jej ujęcia - pomimo sugerującego go tytułu - książka E. Dołganiszewskiej pretendować nie może; zwłaszcza, że i w samej treści rozprawy Autorka nie ustrzegła się kilku błędów i zaniedbań: rozważania nie są potwierdzane odniesieniami do dzieł Cypriana, co skutkuje częstokroć trudnością w zrozumieniu czy jest to myśl Biskupa, czy interpretacja Autorki; podany błędnie na s. 25 tytuł sztandarowego dla eklezjologii dzieła Cypriana De catholicae Ecclesiae unitate; bałagan i bardzo pobieżne omówienie dzieł w rozdziale II; powoływanie się na nauczanie biskupa Kartaginy, gdy tymczasem w przypisie pojawia się autor współczesny (np. ss. 44 i 45) oraz zamieszczanie cytatów w tekście bez wskazywania ich proweniencji. 
Dokonując podsumowania trzeba się cieszyć, że powstała kolejna pozycja dotycząca jednego z najwybitniejszych Ojców Kościoła, który jednak do tej pory nie doczekał się $w$ języku polskim stosownej monografii. Szkoda, że wydaje się to skrótem doktoratu, zrobionym pobieżnie i w wielu miejscach niestarannie. Dla człowieka, szczególnie początkującego patrologa, nie zainteresowanego dogłębnymi rozważaniami eklezjologicznymi, a jednocześnie chcącego poznać postać biskupa Cypriana, praca E. Dołganiszewskiej Biskup Cyprian z Kartaginy. Świadek wiary może czasami być nużąca i trudna, zwłaszcza ostatnie cztery rozdziały. Jednak teolog fundamentalista znajdzie w niej, jeżeli nie ucztę, to z pewnością przystawkę do bogatej myśli teologicznej św. Cypriana $z$ Kartaginy.

Ks. Marcin Wysocki - Olsztyn

\section{Ks. Jan SŁOMKA, Nowe proroctwo. Historia i doktryna montanizmu, Studia Antiquitatis Christianae. Series Nova 4, Katowice 2007, ss. 278.}

Twórczość pisarzy wczesnochrześcijańskich dokonywała się zawsze w konkretnym kontekście. Wpływ na podejmowane tematy i formę miały wydarzenia historyczne, społeczne, polityczne, środowisko danego autora. W sposób jednak szczególny wpływały nań spory dogmatyczne, herezje i schizmy danego okresu. To w odpowiedzi na nie powstała większość dzieł patrystycznych. Nie można więc uprawiać teologii patrystycznej nie znając dogmatycznych zawirowań czasu, w którym żył i tworzył autor będący przedmiotem naszych zainteresowań. Nie tylko więc monografie dotyczące poszczególnych pisarzy, ale także pozycje omawiające poszczególne ruchy heterodoksyjne winny znaleźć się w podstawowej biblioteczce patrologa.

Jednym $z$ takich ruchów, który wywarł ogromny wpływ na Kościół pierwszych wieków i który „w starożytności chrześcijańskiej nie został pominięty w żadnym wykazie herezji" (s. 15) był montanizm. Badania nad tym ruchem, rozpoczęte w XIX wieku, zaowocowały wieloma obcojęzycznymi opracowaniami (J. De Soyres, Montanism and the primitive Church, Cambridge 1877; P.Ch. de Labriolle, La crise montaniste, Paris 1913; A. Faggiotto, L'eresia dei Frigi, Roma 1924; W. Schepelern, Der Montanismus und die phrygischen Kulte, Tübingen 1929; A. Hollard, Deux hérétiques: Marcion et Montan, Paris 1935; G.N. Bonwetsch, Die Geschichte des Montanismus, Hildesheim 1972; F.C. Klawitter, The new prophecy in early Christianity: the origin, nature and development of Montanism, A.D. 165-200, Chicago 1975; D.E. Groh, Utterance and exegesis: biblical interpretation in the Montanist crisis, Lanham 1985; R.E. Heine, The Montanist oracles and testimonia, Macon 1989; D.E. Aune, Prophecy in early Christianity and the ancient Mediterranean world, Eerdmans 1991; 